\section{S NEWS and VIEWS}

Geology at Birmingham :

Prof. L. J. Wills

Prof. L. J. WILLS retires from the chair of geology in the Univerginy of Birmingham at the end of this session. Prof. Wils, like his predecessors, has shown that he is narrow spegialist, and one has only to look at a listof his paper or read his books to realize this. He[has througlout Joen a stratigrapher in the widest Adnse, and when carrying out detailed palæpntdogical work has always had in view the fod that the plants or animals he is describing were ofcelliting organisms making up part of the environmest in which they lived. His early work on the flora and faunas of the Bromsgrove Trias gave a picture of a desert oasis with its inhabitants of scorpions living among the cycads; later his work on the Geological Survey took him on to the North Welsh Lower Palæozoic rocks of the Llangollen syncline, an area excellent for the teaching of young students, and many generations of Birmingham undergraduates have benefited from visits under his guidance to this district. Another line of research which Prof. Wills has followed deals with the history of the Dee and Severn Rivers, and in this he has elucidated the history of these rivers and their relationship to the glacial episodes of the West Midlands and North Wales. Perhaps his most striking pieces of work, however, are his two books, "The Physiographic Evolution of Britain" and the "Palæogeography of the Midlands". These epitomize his teaching of stratigraphy and have influenced teaching not only in Birmingham but also in all the universities throughout Great Britain. His many friends and former students will wish him many years of happy and fruitful retirement, for, like so many geologists, he shows no sign of growing old.<smiles>C1C[C@H]2CC[C@H](C1)C2</smiles>

Prof. F. W. Shotton

Prof. F. W. Shotron, of the University of Sheffield, who succeeds Prof. Wills, is a native of Coventry and was educated at Bablake School, gaining an open scholarship to Sidney Sussex College, Cambridge. After gopduating, ho spent a year on research at Cambridge. During $1928-36$ he was a lecturer in geology in thp Un versity of Birmingham, returning to Calnofidge in the latter year as a lecturer. He sezed in the for from 1940 to 1945 , being geological ofncer to H.Q Middle East during 1941-43, and later he served with the Twenty-First Army Group in Normandy and Belgium. After the War he was appointed professor of geology in the University of Sheffield (see Nature, 155, 664; 1945).

\section{East Malling Research Station: Dr. F. R. Tubbs}

DR. F. R. TuBBs, who has been appointed director of the East Malling Research Station in succession to Sir Ronald Hgtton, took up his new duties on July 1. Dr. Tubbs, tho is forty-one, studied at the Imperial College of Science and Technology. After graduating, he was/awarded a Ministry of Agriculture postgraduate scholarship in plant physiology. For work on the ffect of manurial deficiency upon the mechanical strength of barley straw, carried out under the direction of Dr. F. G. Gregory at Rothamsted, he was awarded the degree of M.Sc. After spending six months at the East Malling and Long Ashton Research Stations, he proceeded to Ceylon in 1930 to found a Department of Plant Physiology at the Tea Research Institute of Ceylon. In 1935 he was awarded the degree of Ph.D. in the University of London for a thesis on the influence of climate and type of pruning on the growth of tea. He also studied methods of vegetative propagation, selection, etc., of the tea bush. After serving in the Army from 1939, he was placed on the retired list in December 1945 with the rank of lieut.-colonel, and returned to Ceylon to resume his investigations at the Tea Research Institute. He returned to Britain in 1948 to take up an appointment as manager in charge of the Horticultural Division of the Food Research Organisation of Messrs. Lever Bros. and Unilever, Ltd., at Sharnbrook, Bedfordshire.

Statistics in the University of London:

Dr. M. G. Kendall

Dr. M. G. KENDaLl has been appointed to a newly created of statistics in the University of London and will take up his appointment in October at the London School of Economics. Dr. Kendall gaduat in mathematjics at Cambridge (Wrangler, Q92 and entere of $k 5$ administrative class of the Ci. Sertice in ${ }_{30}$. He became head of the E\&om mics Intef ifence Branch of the Ministry of Agriculture if 938 , resigning in 1941 to accept the post of statistlelan at the Chamber of Shipping. He became joint assistant general manager at the Chamber in 1946. Dr. Kendall's interests have been largely in mathematical statistics, on which he has written numerous papers; but he has also published work on the applications of statistics to problems of agriculture, shipping, etc. $\mathrm{He}$ has written the standard text-book on the "Advanced Theory of Statistics". Dr. Kendall has also published "Tables of Random Sampling Numbers" (with B. Babington Smith, 1939), "Contributions to the Study of Oscillatory Time-Series" (1946) and "Rank Correlation Methods" (1948). He has been very active in the Royal Statistical Society, in which he has held various offices; the Society awarded him its Silver Medal in 1946. Among the more recent of Dr. Kendall's distinctions have been his election to the International Statistical Institute in 1948, and the award this year of the degree of Sc.D. of the University of Cambridge.

Water-Supply and Rainfall over the British Isles

A statement hofbeen issued by the UnderSecretary of State for Air relating to the recent shortage of cainfdll over the British Isles and its effect upon heldountry's water-supply. In it attention is direct to warnings given by water engineers that gvor much of England there is likely to be a shortagt of water during the next few months, and thif is followed by some statistics of recent rainfall, and some notes on the meteorological aspects of the situation. It is pointed out that the threat of shortage of supply is greatest for south-east England, where reliance is placed mainly on deep-seated water supply; that deep water sources there are dependent for replenishment upon winter rainfall being at least up to the average. Much of the summer fall is lost by evaporation or taken up by vegetation, so that little or none percolates to great depths ; moreover, most of south-east England had less than 70 per cent of its average rainfall during the period October 1948 to March 1949. The winter was not only dry, but also very mild. After the eight winters in the last fifty years that have been both mild and dry, the succeeding spring and summer were dry as often as they were wet, therefore no expectation of a return 